\title{
Chemical quality parameters and bioactive compound content of Brazilian berries
}

\author{
Daniela Mota SEGANTINI ${ }^{1}$, Natalia FALAGÁN², Sarita LEONEL ${ }^{1}$, Joyce Helena MODESTO ${ }^{1}$, \\ Willian Hiroshi Suekane TAKATA ${ }^{1}$, Francisco ARTÉS ${ }^{2 *}$
}

\begin{abstract}
There is a growing consumer demand for higher healthy foods such as berries which are a rich source of phenolic compounds. The current work evaluated blackberry cultivars: Cherokee, Tupy and Xavante; raspberry cultivars: Heritage, Fallgold and Black; and the hybrid Boysenberry. All berries were grown under homogenous subtropical conditions in Brazil. Black raspberry, Cherokee and Tupy blackberry cultivars showed the highest ratio between soluble solid contents and titratable acidity, and Fallgold and Heritage raspberry showed the highest titratable acidity. Total phenolic content ranged from 2.03 to $5.33 \mathrm{~g} \mathrm{~kg}^{-1}$ fresh weight and total anthocyanin content registered values from 0.41 to $1.81 \mathrm{~g} \mathrm{~kg}^{-1}$ fresh weight. The most common phenolic acids were gallic, p-coumaric and ellagic, and for anthocyanins: cyanidin-3-glucoside and malvinidin-3-glucoside. Antioxidant capacity ranged from 14.13 to 21.51 mol equivalent trolox kg-1 fresh weight. Black raspberry, all blackberry cultivars and the Boysenberry hybrid are appropriate to be consumed fresh, while Fallgold and Heritage raspberries are recommended to the food industry. Due to their phenolic richness and antioxidant properties, these fruits are of great interest to the fresh fruit market and to pharmaceutical industries. These results could help breeders and growers when planning the cultivar selection according to their foreseeable destination.
\end{abstract}

Keywords: Rubus spp; Rubus idaeus; phenolics; anthocyanins; antioxidant capacity.

Practical Application: There is a demand for products to meet consumers' need for high quality and healthy foods. The main results of this investigation could be of assistance to growers and breeders when planning the selection of cultivars according to their market destination. These rich in antioxidant fruits are of great interest to the fresh and processed fruit industry, as well as to the pharmaceutical industries.

\section{Introduction}

Dietary phenolics have attracted consumers' attention because of their known antioxidant properties (Manach et al., 2004). Blackberries are currently promoted as being a rich source of phenolics, compounds of interest because of their antioxidant activity as radical scavengers and possible beneficial roles in human health, such as reducing the risk of cancer, cardiovascular disease, and other pathologies (Holiman et al., 1996; Wada \& Ou, 2002; Mertz et al., 2007). In Brazil, due to the increased market demand and the trend to increase and diversify berry crop areas, the cultivation of blackberries (Rubus spp.), blueberries (Vaccinium corymbosum), raspberries (Rubus ideaus) and strawberries (Fragaria ananassa) has greatly increased. In addition to great appeal and use in the Brazilian market, there is the perspective of supplying the Northern Hemisphere in their off-seasons (Fachinello et al., 2011). Although the areas of cultivation are increasing, there is limited information on the quality of blackberry and raspberry fruit from the data collected. Information on the quality attributes and functional properties of these small fruits can guide farmers to choose the cultivars (cvs) that could be planted, thereby enabling greater market visibility, thus adding value to the product. In addition to providing information to consumers and farmers, the characterization should also be taken into account when new breeding programs are designed (Mascarenhas et al., 2012), because genotype, cultivation system or environmental conditions could affect the metabolism and production of antioxidant compounds (Hassimotto et al., 2008; Tarazona-Díaz et al., 2011). Due to health concerns, nowadays consumers increasingly demand fresh and healthy fruits and vegetables (Rodríguez-Hidalgo et al., 2010), and it is well know that some bioactive constituents in natural plant products have the ability to protect from degenerative illnesses and the production of free radicals. The major phenolic compounds in berries are hydrolysable tannins (gallic acid and ellagitannins) and anthocyanins, hydroxycinnamic acids, flavonols, flavan-3-ols, and lower amounts of proanthocyanidins (Siriwoharn \& Wrolstad, 2004). In particular, blackberries and raspberries are very rich in bioactive and antioxidant compounds such as anthocyanins, polyphenols and flavonoids (Hassimotto et al., 2008; Szajdek \& Borowska, 2008). Raspberries possess a large amount of vitamins C, B1, B2 and B6, provitamin A, pectins, salicylic, caffeic and ferulic acids, and mineral salts, highly beneficial for human health. Specifically, anthocyanins are plant pigments with antimutagenic, anti-inflammatory and anticancer effects (Zhang et al., 2012).

${ }^{1}$ Departmento de Horticultura, Faculdade de Ciências Agronômicas - FCA, Universidade Estadual Paulista - UNESP, Botucatu, SP, Brazil

${ }^{2}$ Grupo de Postrecolección y Refrigeración, Departamento de Ingeniería de Alimentos, Universidad Politécnica de Cartagena - UPCT, Cartagena, Murcia, Spain

*Corresponding author: fr.artes@upct.es 
The aim of this work was to monitor the main chemical quality parameters and bioactive compound content of selected raspberry and blackberry cvs and the Boysenberry hybrid (Rubus spp x Rubus idaeus), grown in subtropical Brazilian climate. As far as we know, no previous study has been reported for these cvs in these conditions.

\section{Materials and methods}

\subsection{Sampling}

The plants were cultivated under homogeneous conditions in experimental plots belonging to the Farm Frutopia, Campos do Jordão - SP, Brazil. The climate conditions were classified as subtropical highland, with mild summers and an annual precipitation around $1,800 \mathrm{~mm}$. The plant material consisted of 4-year-old berry plants spaced $3.0 \mathrm{~m} \times 0.6 \mathrm{~m}$, with no additional irrigation. Raspberry cvs: Heritage, Fallgold and Black; blackberry cvs: Tupy, Cherokee and Xavante, and the Boysenberry hybrid (Figure 1) were hand-harvested on January $6^{\text {th }}$ at optimum maturity stage to be commercialized for fresh consumption.

About $1 \mathrm{~kg}$ of sound fruit was randomly selected from each cultivar, free from defects, decay or mechanical damages, and carefully packed in polypropylene trays. The berries were then transported to the Fruit Laboratory of FCA/UNESP/Botucatu - SP, where were kept in a cold room at $2{ }^{\circ} \mathrm{C}$. The next morning the fresh weight (fw), pH, titratable acidity (TA), and soluble solids content (SSC) were monitored. For further assays about $500 \mathrm{~g}$ of pulp fruit of each cv. were freeze-dried (Heto Powerdry LL 1500, USA), packed in Falcon tubes and stored at $-20{ }^{\circ} \mathrm{C}$ for 20 days. Then, freeze-dried samples were transported to the Technical University of Cartagena (Murcia, Spain), where the analyses of bioactive compounds (total phenolic and anthocyanin content and individual polyphenol and anthocyanin content) and antioxidant capacity (AC) were performed.

\subsection{Fresh weight}

Fresh weight (fw) was obtained by weighing samples in a semi-analytical balance (Marte, Brazil), with a maximum load of 2,000 $\mathrm{g}$ and $0.001 \mathrm{~g}$ accuracy. Three repetitions per treatment were performed and each repetition comprised 15 fruits, with a total weight of $100 \mathrm{~g}$.

\subsection{Chemical parameters}

SSC, TA and $\mathrm{pH}$ analyses were performed according to Artés et al. (1993). For that, a juice was prepared by squeezing $100 \mathrm{~g}$ of berries with a commercial blender (Moulinex, Barcelona, Spain). SSC was monitored with a handheld refractometer (Atago $\mathrm{N} 1$, Tokyo, Japan) and expressed in ${ }^{\circ}$ Brix. The $\mathrm{pH}$ was determined with a glass electrode $\mathrm{pH}$-meter (Schott, Piracicaba, Brazil). For monitoring TA, $5 \mathrm{~g}$ of pulp of each cultivar were dissolved in $100 \mathrm{~mL}$ of distilled water, then titrated with $0.1 \mathrm{M} \mathrm{NaOH}$ to $\mathrm{pH} 8.1$ and the results were expressed as $\mathrm{g}$ of citric acid kg-1 fw.

\subsection{Total phenolic and anthocyanin contents}

Total phenolic content (TPC) was determined following the Folin-Ciocalteu method of Singleton \& Rossi (1965) with slight modifications proposed by Martínez-Hernández et al. (2011). $10 \mathrm{mg}$ of freeze-dried sample were dissolved in $3 \mathrm{~mL}$ of methanol, brought to a rotary bath for $1 \mathrm{~h}$ at $4{ }^{\circ} \mathrm{C}$ and $200 \mathrm{rpm}$. After that, the samples were placed in tubes and brought to centrifuge at $4{ }^{\circ} \mathrm{C}, 16,000 \mathrm{rpm}$ for $30 \mathrm{~min}$. An aliquot of supernatant was collected $(19.2 \mu \mathrm{L})$, which reacted with the Folin reagent $29 \mu \mathrm{L}$ ( $1: 1 \mathrm{v} / \mathrm{v}$ Folin reagent: water), after $3 \mathrm{~min} 192 \mu \mathrm{L}$ of a $\mathrm{NaOH} 0.4 \%$ and $2 \% \mathrm{NaHCO}_{3}$ were added to a distilled water solution. After $1 \mathrm{~h}$ of reaction, samples were disposed in a plate and analyzed in a spectrophotometer (Tecan Infinite M2000, Männedorf, Switzerland) at $750 \mathrm{~nm}$. TPC was expressed as g of gallic acid equivalents per $\mathrm{kg}$ of $\mathrm{fw}\left(\mathrm{g} \mathrm{GAE} \mathrm{kg}^{-1} \mathrm{fw}\right)$.

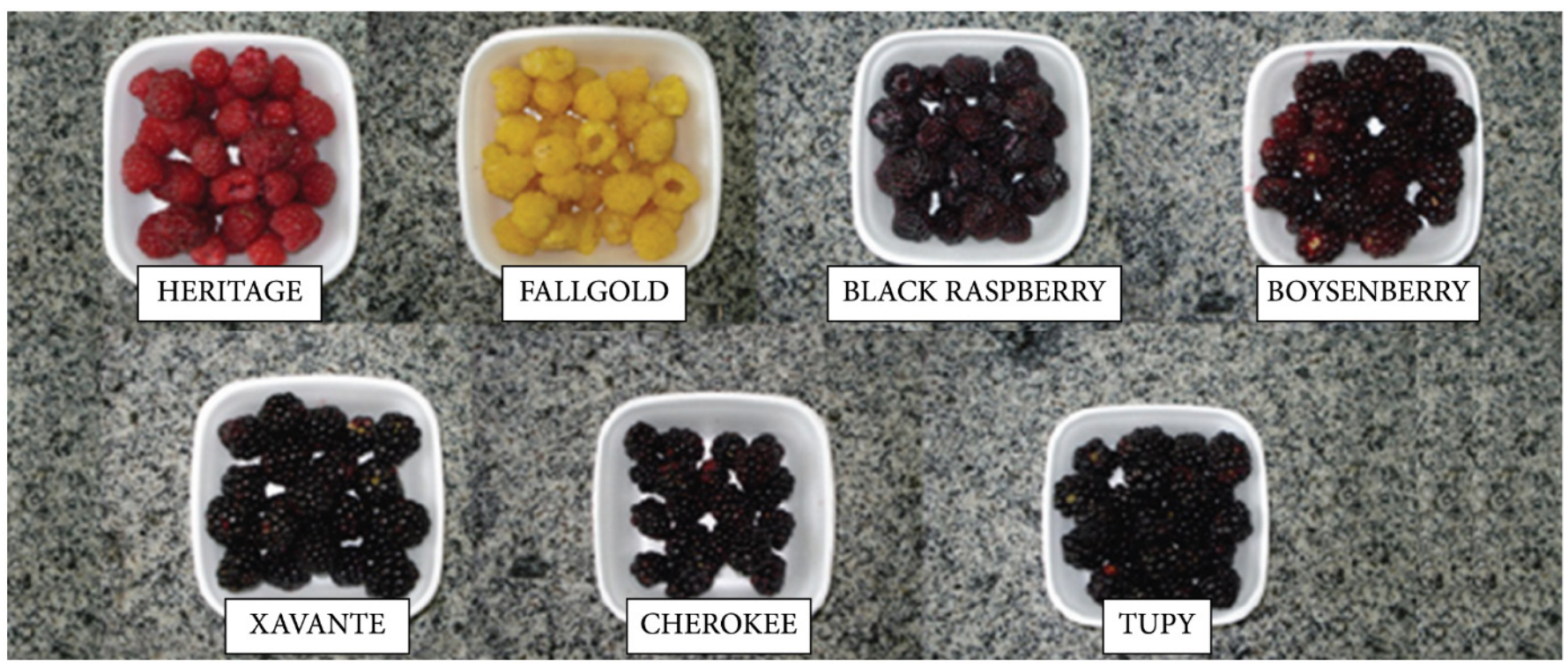

Figure 1. Visual aspect of raspberry and blackberry cultivars at harvest. 
Total anthocyanin content (TAC) analyses were performed following the method proposed by Lee et al. (2002) with slight modifications. About $30 \mathrm{mg}$ of freeze-dried pulp were dissolved in $4 \mathrm{~mL}$ of aqueous formic acid (5\%) and homogenized in a high speed blender (Ultraturrax T-18 basic, IKA, China) and placed in an ultrasonic bath for $10 \mathrm{~min}$. The samples were centrifuged at $14,000 \mathrm{rpm}$ for $15 \mathrm{~min}$ at $4{ }^{\circ} \mathrm{C}$. The supernatant was collected and saved; then a new extraction began with the precipitate following the same steps. Both extracts were mixed and eluted in a Sep-Pak C-18 (Waters Associates Inc., Milford, MA, USA), already activated with methanol, water and air. The liquid obtained in this first filtration was discarded and anthocyanins were recovered with methyl solution. A second filtration was carried out with $5 \mathrm{~mL}$ of $0.1 \mathrm{M} \mathrm{HCl}$ in methanol, $90 \mu \mathrm{L}$ obtained from the second filter were collected to react with $210 \mu \mathrm{L}$ of methanol solution containing $1 \% \mathrm{HCl}$. The absorbance was measured at $520 \mathrm{~nm}$ using a Multiskan plate reader spectrophotometer (Tecan Infinite M2000, Männedorf, Switzerland) and the results were expressed as $\mathrm{g}$ of cyanidin-3-glucoside equivalents $\mathrm{kg}^{-1} \mathrm{fw}$ (g CGE kg${ }^{-1} \mathrm{fw}$ ).

\subsection{Antioxidant capacity}

The AC was determined using a methodology adapted from Brand-Williams et al. (1995), with slight modifications reported by Martínez-Hernández et al. (2011). For this purpose, $10 \mathrm{mg}$ of freeze-dried samples were dissolved in $3 \mathrm{~mL}$ of methanol, placed in a cold bath at $4{ }^{\circ} \mathrm{C}$ and $200 \mathrm{rpm}$ for $1 \mathrm{~h}$. After that, the samples were packed in tubes and centrifuged at $4{ }^{\circ} \mathrm{C}$ and $16,000 \mathrm{rpm}$ for $1 \mathrm{~h} .21 \mu \mathrm{L}$ of supernatant were collected to react with $194 \mu \mathrm{L}$ of a 2,2-diphenyl-1-picrylhydrazyl methyl solution for $20 \mathrm{~min}$. Next, the samples were analyzed in a Multiskan plate reader (Tecan Infinite M2000, Männedorf, Switzerland) at $515 \mathrm{~nm}$. The AC was expressed as mol eq. trolox $\mathrm{kg}^{-1} \mathrm{fw}$ (Sigma-Aldrich, Madrid, Spain).

\subsection{Individual polyphenols and anthocyanin content}

Individual polyphenols and anthocyanins were monitored following the method adapted from García-Viguera et al. $(1997 ; 1998)$. For this purpose, $10 \mathrm{mg}$ of freeze-dried sample were dissolved in $5 \mathrm{~mL}$ of an aqueous solution with $5 \%$ formic acid, and placed in an ultrasonic bath at room temperature for $10 \mathrm{~min}$. After this period, the samples were centrifuged at $16,000 \mathrm{rpm}$ for $20 \mathrm{~min}$ at $4{ }^{\circ} \mathrm{C}$; supernatant was collected and stored at $5^{\circ} \mathrm{C}$. The same process was repeated with the precipitate to yield a second extract. Both supernatants were mixed and filtered on Sep-Pak C-18 cartridges previously activated, and the collected content of the cartridges was taken to a rotavapor at $35^{\circ} \mathrm{C}$ until dry. The dried extracts were dissolved in a methanol solution: formic acid $5 \%$ and then filtered. The samples were analyzed by Ultra Performance Liquid Chromatography (UPLC, Shimadzu, Kyoto, Japan) at 280 and $320 \mathrm{~nm}$ for polyphenols and $520 \mathrm{~nm}$ for anthocyanins. The analyses were conducted at constant temperature of $25^{\circ} \mathrm{C}$, using a $1 \mathrm{~mL} \mathrm{~min}{ }^{-1}$ flow rate and an injected sample volume of $20 \mu \mathrm{L}$. Nanopure water containing $5 \%(\mathrm{v} / \mathrm{v})$ formic acid (A) and methanol (B) were used as the mobile phases. Elution conditions were as follow: $15 \% \mathrm{~B}, 0-15 \mathrm{~min}$; $15 \% \mathrm{~B}$ to $30 \% \mathrm{~B}, 15-20 \mathrm{~min} ; 30 \% \mathrm{~B}, 20-25 \mathrm{~min} ; 30 \% \mathrm{~B}$ to $95 \%$
B, 25-33 min; to $15 \%$ B, 33-40 min. Concentrations of targeted compounds were determined from external calibration curve derived from 6 data points (Sigma-Aldrich, Madrid, Spain). Standards for quantification were provided by Polyphenols Laboratories A.S. (Sandnes, Norway) while individual phenolics by Sigma-Aldrich (Madrid, Spain). TAC was calculated by addition of the amounts of the anthocyanins detected in each chromatogram (García-Viguera et al., 1998).

\subsection{Experimental design and statistical analysis}

The completely randomized experimental design consisted of 7 treatments (cvs), with 3 replicates. Each replicate consisted of 3 samples of approximately $100 \mathrm{~g}$. Each analysis was made in triplicate. Statistical analysis was performed with SAS (SAS Institute Inc., Cary, NC) and an analysis of variance was used to determine significant differences $(\mathrm{p}<0.05$; Tukey's test $)$ in quality parameters. The correlation between AC and TPC was determined by the Pearson's correlation test. Results for individual polyphenols and anthocyanins were expressed as mean \pm standard deviation.

\section{Results and discussion}

\subsection{Fresh weight}

Heritage and Fallgold raspberries showed the lowest fresh weight average (2.63 and $2.86 \mathrm{~g}$, respectively), while Tupy blackberry $\mathrm{cv}$. reached the highest with $6.56 \mathrm{~g}$. The Boysenberry hybrid showed an intermediate value of $4.43 \mathrm{~g}$ (Table 1). Besides flavor, size is an important attribute of quality in breeding programs (Raseira \& Franzon, 2012). It is highly related to weight. These results agree with those reported by Moura et al. (2012), who found that Black Raspberry and Heritage cvs had low fresh weight average ( 2.1 and $2.6 \mathrm{~g}$, respectively), and Boysenberry hybrid grown in Minas Gerais (Brazil) registered $5.3 \mathrm{~g}$. It seems most likely that these slight differences are due to the different cultivation techniques, and/or soil and weather conditions, which may slightly change the quality parameters.

\subsection{Chemical parameters}

Black Raspberry showed the highest $\mathrm{pH}$ value (3.25). No difference in $\mathrm{pH}$ was found among the other $\mathrm{cvs}$ which were in the range from 2.84 to 2.90 (Table 1). Heritage and Fallgold raspberry cvs showed the highest TA levels with 13.6 and $12.7 \mathrm{~g}$ citric acid kg-1 fw, respectively. Results in Heritage cv. contrast with the lower value ( $7.2 \mathrm{~g}$ citric acid kg-1 $\mathrm{fw}$ ) previously found by García-Viguera et al. (1998) in this cv growing under the dryer and colder Mediterranean climate of Southeastern Spain (Nerpio, Albacete). This difference could be influenced by the cultivation system and growing conditions. The cvs Fallgold and Heritage showed the lowest SSC values with 7.26 and $7.56^{\circ} \mathrm{Brix}$, respectively. Xavante blackberry and Black raspberry registered the highest SSC values, with 9.93 and $9.83^{\circ}$ Brix, respectively (Table 1).

Regarding the SSC/TA ratio, blackberry cvs and Black raspberry registered the highest values, reaching an average of 10.81. According to these data, these cultivars should be 
preferably destined to direct fresh consumption because this ratio is very appreciated by the consumers. In fact, it is generally recognized that fruits with balanced flavor (sweet/acidity) should be intended to the fresh market (Raseira \& Franzon, 2012). These results evidenced the influence of genotypes and growing conditions on the chemical characteristics and are in agreement with Hassimotto et al. (2008) who found SSC values of different blackberries cvs which ranged between 6.10 and $9.32^{\circ} \mathrm{Brix}$, TA between 12.6 and $15.4 \mathrm{~g}$ acid citric $\mathrm{kg}^{-1} \mathrm{fW}$ and SSC/TA ratio between 4.01 and 7.39. In two species of blackberry (Rubus glaucus and Rubus adenotrichus), the SSC were 10 and $12^{\circ}$ Brix respectively, $\mathrm{pH} 2.55$ and 2.67, and TA 25.5 and $26.7 \mathrm{~g}$ citric acid $\mathrm{kg}^{-1} \mathrm{fw}$ (Mertz et al. 2007). Similarly, SSC values ranged from 8.3 to $12.8^{\circ} \mathrm{Brix}$ in raspberries (Krüger et al., 2011).

\subsection{Total phenolic and anthocyanin content}

A large difference in the TPC and TAC of the analyzed raspberry cvs was found. Fallgold showed the lowest TPC (2.03 $\left.\mathrm{g} \mathrm{GAE} \mathrm{kg}^{-1} \mathrm{fw}\right)$ and the lowest TAC $\left(0.04 \mathrm{~g} \mathrm{CGE} \mathrm{kg}^{-1} \mathrm{fw}\right)$, whereas Black Raspberry showed the highest level, respectively $5.33 \mathrm{~g} \mathrm{GAE} \mathrm{kg}^{-1} \mathrm{fw}$ and $1.83 \mathrm{~g} \mathrm{CGE} \mathrm{kg}^{-1}$ fw (Table 2).
These results agree with those of Reyes-Carmona et al. (2005) who assessed different blackberry cvs in Mexico, reporting that cultivation sites and genotypic differences provided significant differences in the TPC and TAC among cvs. In raspberries, Mazur et al. (2014) also highlighted this fact, finding an important genotype influence on bioactive compounds. In Choctaw and Kiowa blackberries cvs, 4.17 and $5.22 \mathrm{~g} \mathrm{GAE} \mathrm{kg}^{-1} \mathrm{fw}$ respectively, and a TAC between 1.11 and $1.23 \mathrm{~g} \mathrm{CGE} \mathrm{kg}^{-1} \mathrm{fw}$ (Sellappan et al., 2002). We also found similarities with Hassimotto et al. (2008), who reported ranges of 3.41 to $4.99 \mathrm{~g} \mathrm{GAE} \mathrm{kg}^{-1} \mathrm{fw}$ in the TPC of blackberries and TAC ranges of 1.16 to $1.94 \mathrm{~g} \mathrm{CGE} \mathrm{kg}^{-1} \mathrm{fw}$. However, the current results contrast with those of Souza et al. (2014), which reported higher TPC in different blackberries cvs with values of around $8.50 \mathrm{~g} \mathrm{GAE} \mathrm{kg}^{-1} \mathrm{fw}$, red raspberries $3.57 \mathrm{~g} \mathrm{GAE} \mathrm{kg}^{-1} \mathrm{fw}$ or blueberries over $3.00 \mathrm{~g} \mathrm{GAE} \mathrm{kg}^{-1} \mathrm{fw}$. Lower quantities were detected in other studies. Respectively, Fallgold and Heritage cvs showed 1.48 and $1.90 \mathrm{~g} \mathrm{GAE} \mathrm{kg}^{-1} \mathrm{fw}$ (Pantelidis et al., 2007). This difference could be explained because these parameters can change according to cv., cultivation techniques, type of soil and/ or climate conditions. As an example, Castellarin et al. (2007) reported that TAC in grape berries is increased with water stress. This deficit promoted the expression of the genes responsible for the biosynthesis of anthocyanins.

Table 1. Weight and chemical parameters [pH, titratable acidity (TA), soluble solid content (SSC) and maturity index (SSC/TA ratio)] of raspberries, blackberries cultivars and hybrid analyzed.

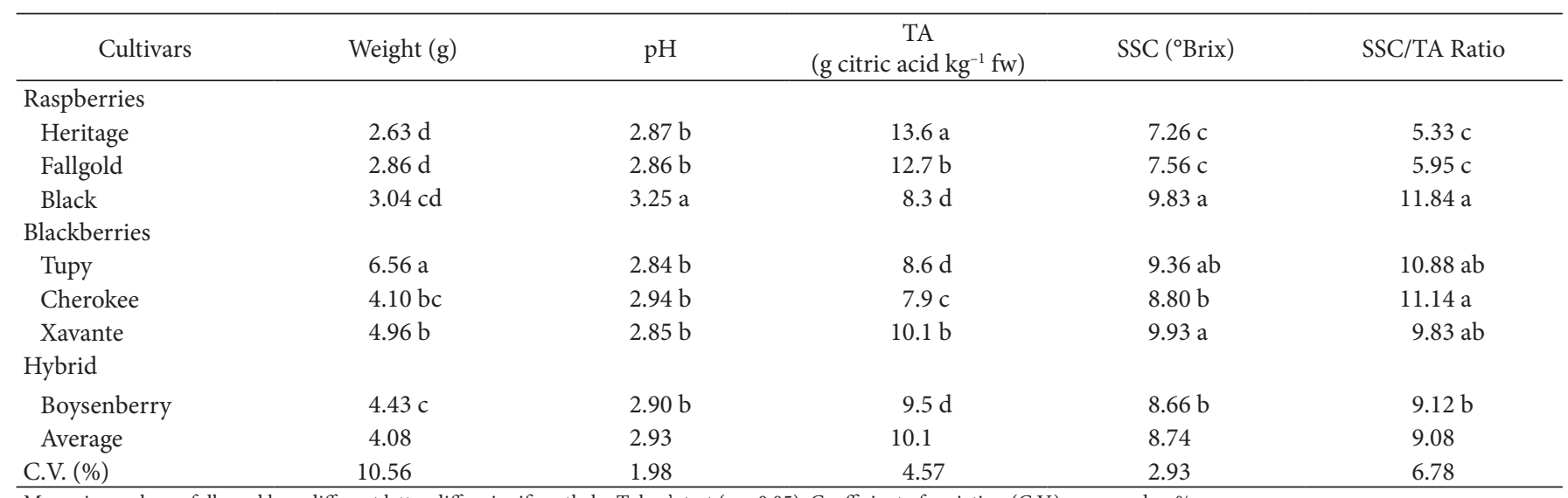

Means in a column followed by a different letter differ significantly by Tukey's test $(\mathrm{p}<0.05)$. Coefficient of variation $($ C.V.) expressed as $\%$.

Table 2. Total phenolic content (TPC), total anthocyanin content (TAC) and antioxidant capacity (AC) of raspberries, blackberries and the hybrid studied.

\begin{tabular}{|c|c|c|c|}
\hline & TPC $\left(\mathrm{g} \mathrm{GAE} \mathrm{kg}^{-1} \mathrm{fw}\right)$ & TAC $\left(\mathrm{g} \mathrm{CGE} \mathrm{kg}^{-1} \mathrm{fw}\right)$ & $\mathrm{AC}\left(\mathrm{mol}\right.$ eq. trolox $\left.\mathrm{kg}^{-1} \mathrm{fw}\right)$ \\
\hline \multicolumn{4}{|l|}{ Raspberries } \\
\hline Heritage & $3.58 \mathrm{c}$ & $0.53 \mathrm{e}$ & $14.70 \mathrm{c}$ \\
\hline Fallgold & $2.03 \mathrm{~d}$ & $0.04 \mathrm{f}$ & $14.13 \mathrm{c}$ \\
\hline Black Raspberry & $5.33 \mathrm{a}$ & $1.81 \mathrm{a}$ & $21.51 \mathrm{a}$ \\
\hline \multicolumn{4}{|l|}{ Blackberries } \\
\hline Tupy & $3.72 \mathrm{~cd}$ & $0.63 \mathrm{de}$ & $15.37 \mathrm{c}$ \\
\hline Cherokee & $4.19 \mathrm{bc}$ & $0.80 \mathrm{~cd}$ & $19.75 \mathrm{a}$ \\
\hline Xavante & $4.44 \mathrm{~b}$ & $1.04 \mathrm{bc}$ & $21.26 \mathrm{a}$ \\
\hline \multicolumn{4}{|l|}{ Hybrid } \\
\hline Boysenberry & $4.18 \mathrm{bc}$ & $1.07 \mathrm{~b}$ & $17.79 \mathrm{~b}$ \\
\hline Average & 3.92 & 0.84 & 17.78 \\
\hline C.V. $(\%)$ & 5.58 & 9.95 & 3.70 \\
\hline
\end{tabular}

Means in a column followed by a different letter differ significantly by Tukey's test $(\mathrm{p}<0.05)$. Coefficient of variation $(\mathrm{C} . \mathrm{V}$.) expressed as $\%$. 


\subsection{Antioxidant capacity}

The AC values ranged from 14.13 to 21.51 mol eq. trolox kg-1 (Table 2), confirming the richness of antioxidant compounds in these berries. For example, Kuskoski et al. (2006) reported that strawberry pulp showed an AC of 9.2 mol eq. trolox $\mathrm{kg}^{-1}$, pineapple pulp $0.5 \mathrm{~mol}$ eq. trolox $\mathrm{kg}^{-1}$, grape pulp $7.0 \mathrm{~mol}$ eq. trolox $\mathrm{kg}^{-1}$ and mango pulp $12.1 \mathrm{~mol} \mathrm{eq}$. trolox $\mathrm{kg}^{-1}$. Black Raspberry, Xavante and Cherokee cvs showed the highest AC, with 21.51, 21.26 and $19.75 \mathrm{~mol}$ eq. trolox $\mathrm{kg}^{-1}$, respectively (Table 2). Among the raspberries, Fallgold (yellow pulp) showed the lowest AC, with 14.13 mol eq. trolox $\mathrm{g}^{-1}$. This cultivar showed vestiges of anthocyanins, the low anthocyanins content could be related with its low AC; since anthocyanins are phenolic compounds they have antioxidant properties. In the current study, the correlation coefficient between TPC and AC was $\mathrm{r}^{2}=0.79$ showing that the AC is well related with TPC (Figure 2).

These results are in agreement with those of Cho et al. (2005), who found a correlation coefficient of $r^{2}=0.72$, when using the oxygen radical-absorbing capacity (ORAC) method, and $\mathrm{r}^{2}=0.88$ when using the photochemiluminescence assay method. These authors reported that several types of phenolics in the fresh extracts varied in their ability to scavenge peroxyl and superoxide anion radicals. However, Sellappan et al. (2002) found higher correlation coefficient in blueberries and blackberries cvs $\left(r^{2}=0.98\right)$, using the ABTS assay. As observed, the method used to determine AC could influence the correlation.

\subsection{Individual polyphenol and anthocyanin content}

Ellagic acid was found in all studied cvs, but at low levels ( 2.67 to $18.03 \mathrm{mg} \mathrm{kg}^{-1} \mathrm{fw}$ ) while $\mathrm{p}$-coumaric acid was detected at high levels ( 670.26 to $710.35 \mathrm{mg} \mathrm{kg}^{-1}$ ), although this acid was not present in Tupy and Xavante cvs (Table 3). In Kiowa and Choctaw blackberry cvs, Sellappan et al. (2002) reported high values of ellagic acid (300.1 and $338.1 \mathrm{mg} \mathrm{kg}^{-1} \mathrm{fw}$, respectively) and low values of p-coumaric acid (4.0 and $20.8 \mathrm{mg} \mathrm{kg}^{-1} \mathrm{fw}$ ). In yellow and red raspberry cvs the presence of ellagic acid

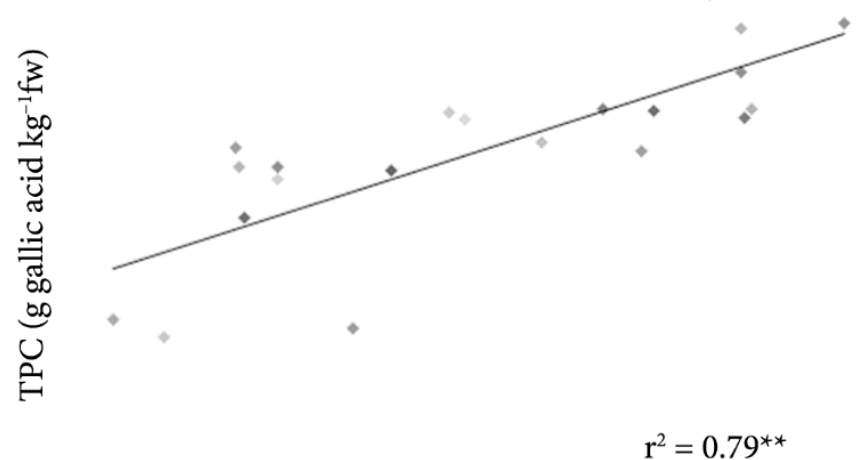

\section{AC (mol eq Trolox $\left.\mathrm{kg}^{-1} \mathrm{fw}\right)$}

Figure 2. Correlation between total phenolic content (TPC) and antioxidant capacity (AC) in raspberry and blackberry cultivars. $\left({ }^{*}\right.$ Significative Pearson's Correlation, $\left.\mathrm{p}<0.05\right)$.

Table 3. Individual polyphenol and anthocyanin content in raspberries, blackberries and the hybrid analyzed.

\begin{tabular}{|c|c|c|c|c|c|c|}
\hline \multicolumn{7}{|c|}{ Individual polyphenol content $\left(\mathrm{mg} \mathrm{kg}^{-1} \mathrm{fw}\right)$} \\
\hline Cultivars & Gallic acid & Ferulic acid & Caffeic acid & Ellagic acid & \multicolumn{2}{|c|}{ p-Coumaric acid } \\
\hline \multicolumn{7}{|l|}{ Raspberries } \\
\hline Heritage & $25.78 \pm 0.12$ & nd & $1623 \pm 0.03$ & $2.67 \pm 0.02$ & \multicolumn{2}{|c|}{$710.03 \pm 0.33$} \\
\hline Fallgold & $145.82 \pm 0.05$ & nd & nd & $13.90 \pm 0.10$ & \multicolumn{2}{|c|}{$678.26 \pm 0.26$} \\
\hline Black Raspberry & $92.08 \pm 0.04$ & nd & nd & $18.03 \pm 0.03$ & \multicolumn{2}{|c|}{$670.26 \pm 0.18$} \\
\hline \multicolumn{7}{|l|}{ Blackberries } \\
\hline Tupy & nd & nd & nd & $10.79 \pm 0.01$ & \multicolumn{2}{|c|}{ nd } \\
\hline Cherokee & $115.90 \pm 0.04$ & nd & nd & $15.69 \pm 0.02$ & \multicolumn{2}{|c|}{$671.55 \pm 0.15$} \\
\hline Xavante & nd & nd & nd & $14.60 \pm 0.28$ & \multicolumn{2}{|c|}{ nd } \\
\hline \multicolumn{7}{|l|}{ Hybrid } \\
\hline Boysenberry & nd & nd & nd & $11.66 \pm 0.08$ & \multicolumn{2}{|c|}{ nd } \\
\hline \multicolumn{7}{|c|}{ Individual anthocyanin content $\left(\mathrm{mg} \mathrm{kg}^{-1} \mathrm{fw}\right)$} \\
\hline Cultivars & Dp-3-glc & Cy-3-gal & Cy-3-glu & Mv-3-gluc & Pt-3-gluc & Pg-3-gluc \\
\hline \multicolumn{7}{|l|}{ Raspberries } \\
\hline Heritage & $49.26 \pm 0.04$ & nd & $74.49 \pm 0.08$ & $56.45 \pm 1.02$ & $1.07 \pm 0.04$ & nd \\
\hline Fallgold & nd & nd & nd & nd & nd & nd \\
\hline Black Raspberry & nd & nd & $60.44 \pm 0.06$ & $9.53 \pm 0.04$ & nd & nd \\
\hline \multicolumn{7}{|l|}{ Blackberries } \\
\hline Tupy & nd & nd & $48.08 \pm 0.03$ & $9.53 \pm 0.21$ & nd & nd \\
\hline Cherokee & nd & nd & $149.07 \pm 0.05$ & $25.72 \pm 0.03$ & nd & nd \\
\hline Xavante & nd & nd & $81.71 \pm 0.05$ & $7.17 \pm 0.07$ & nd & nd \\
\hline \multicolumn{7}{|l|}{ Hybrid } \\
\hline Boysenberry & $41.86 \pm 0.05$ & nd & $30.40 \pm 0.03$ & $2.96 \pm 0.02$ & nd & nd \\
\hline
\end{tabular}

Dp-3-glc = delphinidin-3-glucoside, Cy-3-gal = Cyanidin-3-galactoside, Cy-3-glu = Cyanidin-3-glucoside, Mv-3-gluc = Malvinidin-3-glucoside, Pt-3-gluc = Petunidin-3-glucoside, Pg-3-gluc $=$ Pelargonidin-3-glucoside. nd=not detected. 
and derivatives values ranged from 970 to $1560 \mathrm{mg} \mathrm{kg}^{-1} \mathrm{fw}$ (Wang et al., 2008). The discrepancy among these studies can be explained by the different cvs and growing conditions evaluated. Ferulic acid was not detected in any $\mathrm{cv}$ studied. Gallic acid was not detected in Tupy, Xavante and Boysenberry cvs and caffeic acid $\left(1,623.98 \mathrm{mg} \mathrm{kg}^{-1}\right)$ shown only in Heritage cv. (Table 3 ). The same phenolic acids were identified by Sellappan et al. (2002) in Kiowa and Choctaw cvs with levels of gallic acid between 41.20 and $64.20 \mathrm{mg} \mathrm{kg}^{-1} \mathrm{fw}$, ferulic acid between 29.90 and $35.10 \mathrm{mg} \mathrm{kg}^{-1} \mathrm{fw}$ and caffeic acid between 13.80 and $36.40 \mathrm{mg} \mathrm{kg}^{-1} \mathrm{fw}$, respectively. Regarding the individual anthocyanins, the most abundant were cyanidin-3-glucoside and malvidin-3-glucoside (Table 3). This agrees with Wang et al. (2008), who reported that cyanidin-3-glucoside is the prevalent anthocyanin and responsible for the AC in blackberries. Similarly, six blackberry genotypes analyzed by Cho et al. (2005) showed that distribution of cyanidin aglycones in each cultivar ranged from 75 to $84 \%$ for cyanidin 3 -glucoside, from 1 to $12 \%$ for cyanidin 3-rutinoside, from 4 to $8 \%$ for cyanidin 3-dioxaloyglucoside, from 3 to $8 \%$ for cyanidin 3-dioxaloylglucoside, and from 2 to $3 \%$ for cyanidin 3-(malonyl) glucoside. Other anthocyanins were identified as delfinidin-3-glucoside (between 41.86 and $49.26 \mathrm{mg} \mathrm{kg}^{-1} \mathrm{fw}$ ), malvinidin-3-glucoside (2.96 to $56.45 \mathrm{mg} \mathrm{kg}^{-1} \mathrm{fw}$ ). Petunidin-3-glucoside ( $1.07 \mathrm{mg} \mathrm{kg}^{-1} \mathrm{fw}$ ) was detected only in Heritage raspberry cv. In Fallgold cv. individual anthocyanins were not detected, which may be due to be the yellow color of the flesh of this cultivar (Table 3).

In the current work, the main anthocyanin found in the genotypes was cyaniding-3-glucoside (Table 3 ). These finding show that this anthocyanin is the most prevalent in blackberries and raspberries. Similarly, in two species of blackberry (Rubus glaucus and Rubus adenotrichus), Cho et al. (2005), verified the prevalence of cyanidin-3-glucoside that was found in 680 and $380 \mathrm{mg} \mathrm{kg}^{-1} \mathrm{fw}$, respectively, while cyanidin-3-rutinoside (630 mg kg-1 fw) was found only in Rubus glaucus.

\section{Conclusions}

According to chemical quality parameters, Black raspberry, Cherokee, Tupy and Xavante cvs and the Boysenberry hybrid should be preferably intended for fresh consumption because of their high SSC/TA ratio. However Fallgold and Heritage raspberry cvs should be preferably destined to the frozen fruit and jam industries.

The concentration of individual polyphenols varied among cvs and the most common polyphenols were gallic, $\mathrm{p}$-coumaric and ellagic acids, while cyanidin-3-glucoside and malvinidin-3-glucoside were the most common anthocyanins. The $\mathrm{AC}$ was generally highly related with the TPC in the analyzed cvs. The highest TPC and TAC values were found for Black raspberry and their AC reached a high level. Fallgold reached the lowest TPC and TAC values and their AC was among the lowest levels. Cherokee, Tupy and Xavante raspberry cvs, and the Boysenberry hybrid reached intermediate values. These results may be of help when planning assays for breeding and selecting cultivars with high antioxidant properties, which could be of great interest to the fresh and processed food and pharmaceutical industries.

\section{Abbreviations}

Antioxidant capacity: AC; Cultivars: cvs; C.V.: Coefficient of variation; Cyanidin-3-galactoside: Cy-3-gal; Cyanidin-3-glucoside: Cy-3-glu; Cyanidin-3-glucoside equivalents: CGE; Delphinidin-3-glucoside: Dp-3-glc; Fresh weight: fw; Gallic acid equivalents: GAE; Malvinidin-3-glucoside: Mv-3-gluc; Petunidin-3-glucoside: Pt-3-gluc; Pelargonidin-3-glucoside: Pg-3-gluc; Soluble solid content: SSC; Total anthocyanin content: TAC; Total phenolic content: TPC; Tritatable acidity: TA.

\section{Acknowledgements}

We are grateful to Dr. C. García-Viguera (CEBAS-CSIC, Murcia, Spain) and Dr. E. Aguayo (GPR-UPCT, Cartagena, Spain), for their help in some UPLC analyses. We acknowledge Farm Frutopia (Campos do Jordão, São Paulo, Brazil) for providing berries. We also gratefully acknowledge the Institute of Plant Biotechnology of the UPCT for providing some facilities.

\section{References}

Artés, F., Escriche, A. J., Martínez, J. A., \& Marín, J. G. (1993). Quality factors in four varieties of melon (Cucumis melo L). Journal of Food Quality, 16(2), 91-100. http://dx.doi.org/10.1111/j.1745-4557.1993. tb00352.x.

Brand-Williams, W., Cuvelier, M. E., \& Berset, C. (1995). Use of a free radical method to evaluate antioxidant activity. $L W T$-. Food Science and Technology, 28, 25-30.

Castellarin, S. D., Matthews, M. A., Di Gaspero, G., \& Gambetta, G. A. (2007). Water deficits accelerate ripening and induce changes in gene expression regulating flavonoid biosynthesis in grape berries. Planta, 227(1), 101-112. http://dx.doi.org/10.1007/s00425-0070598-8. PMid:17694320.

Cho, M. J., Howard, L. R., Prior, R. L., \& Clark, J. R. (2005). Flavonol glycosides and antioxidant capacity of various blackberry and blueberry genotypes determined by high-performance liquid chromatography/ mass spectrometry. Journal of the Science of Food and Agriculture, 85(13), 2149-2158. http://dx.doi.org/10.1002/jsfa.2209.

Fachinello, J. C., Pasa, M. S., Schmtiz, J. D., \& Betemps, D. L. (2011). Situação e perspectivas da fruticultura de clima temperado no Brasil. Revista Brasileira de Fruticultura, 33(spe1), 109-120. http://dx.doi. org/10.1590/S0100-29452011000500014.

García-Viguera, C., Zafrilla, P., \& Tomás-Barberán, F. A. (1997). Determination of authenticity of fruit jams by HPLC analysis of anthocyanins. Journal of the Science of Food and Agriculture, 73(2), 207213. http://dx.doi.org/10.1002/(SICI)1097-0010(199702)73:2<207::AIDJSFA703>3.0.CO;2-8.

García-Viguera, C., Zafrilla, P., Artés, F., Romero, F., Abellán, P., \& TomásBarberán, F. (1998). Colour and anthocyanin stability of red raspberry jam. Journal of the Science of Food and Agriculture, 78(4), 565-573. http://dx.doi.org/10.1002/(SICI)1097-0010(199812)78:4<565::AIDJSFA $154>3.0 . C O ; 2-P$.

Hassimotto, N. M. A., Mota, R. V., Cordenunsi, B. R., \& Lajolo, F. M. (2008). Physicochemical characterization and bioactive compounds of blackberry fruits (Rubus sp) grown in Brazil. Ciencia e Tecnologia de Alimentos, 28(3), 702-708. http://dx.doi.org/10.1590/S010120612008000300029.

Holiman, P. C. H., Hertog, M. G. L., \& Katan, M. B. (1996). Analysis and health effects of flavonoids. Food Chemistry, 57(1), 43-46. http:// dx.doi.org/10.1016/0308-8146(96)00065-9. 
Krüger, E., Dietrich, H., Schöpplein, E., Rasim, S., \& Kürbel, P. (2011). Cultivar, storage conditions and ripening effects on physical and chemical qualities of red raspberry fruit. Postharvest Biology and Technology, 60(1), 31-37. http://dx.doi.org/10.1016/j.postharvbio.2010.12.001.

Kuskoski, E. M., Asuero, A. G., Morales, M. T., \& Fett, R. (2006). Frutos tropicais silvestres e polpas de frutas congeladas: atividade antioxidante, polifenóis e antocianinas. Ciência Rural, 36(4), 12831287. http://dx.doi.org/10.1590/S0103-84782006000400037.

Lee, J., Durst, R. W., \& Wrolstad, R. E. (2002). Impact of juice processing on blueberry anthocyanins and polyphenolics: Comparison of two treatments. Journal of Food Science, 67(5), 1660-1667. http://dx.doi. org/10.1111/j.1365-2621.2002.tb08701.x.

Manach, C., Scalbert, A., Morand, C., Rémésy, C., \& Jiménez, L. (2004). Polyphenols: food sources and bioavailability. The American Journal of Clinical Nutrition, 79(5), 727-747. PMid:15113710.

Martínez-Hernández, G. B., Gómez, P. A., Pradas, I., Artés, F., \& Artés-Hernández, F. (2011). Moderate UV-C pretreatment as a quality enhancement tool in fresh-cut Bimi broccoli. Postharvest Biology and Technology, 62(3), 327-337. http://dx.doi.org/10.1016/j. postharvbio.2011.06.015.

Mascarenhas, R. D. J., Silva, S. D. M., Lima, M. A. C. D., Mendonça, R. M. N., \& Holschuh, H. J. (2012). Characterization of maturity and quality of Brazilian apirenic grapes in the São Francisco river Valley. Food Science and Technology (Campinas.), 32(1), 26-33. http:// dx.doi.org/10.1590/S0101-20612012005000010.

Mazur, S. P., Nes, A., Wold, A. B., Remberg, S. F., \& Aaby, K. (2014). Quality and chemical composition of ten red raspberry (Rubus idaeus L.) genotypes during three harvest seasons. Food Chemistry, 160, 233-240. http://dx.doi.org/10.1016/j.foodchem.2014.02.174. PMid:24799233.

Mertz, C., Cheynier, V., Günata, Z., \& Brat, P. (2007). Analysis of phenolic compounds in two blackberry species (Rubus glaucus and Rubus adenotrichus) by high-performance liquid chromatography with diode array detection and electrospray ion trap mass spectrometry. Journal of Agricultural and Food Chemistry, 55(21), 8616-8624. http://dx.doi.org/10.1021/jf071475d. PMid:17896814.

Moura, P. H. A., Campagnolo, M. A., Pio, R., Curi, P. N., Assis, C. N., \& Silva, T. C. (2012). Fenologia e produção de cultivares de framboeseiras em regiões subtropicais no Brasil. Pesquisa Agropecuaria Brasileira, 47(12), 1714-1721. http://dx.doi.org/10.1590/S0100204X2012001200006.

Pantelidis, G. E., Vasilakakis, M., Manganaris, G. A., \& Diamantidis, G. R. (2007). Antioxidant capacity, phenol, anthocyanin and ascorbic acid contents in raspberries, blackberries, red currants, gooseberries and cornelian cherries. Food Chemistry, 102(3), 777-783. http:// dx.doi.org/10.1016/j.foodchem.2006.06.021.
Raseira, M. C. B., \& Franzon, R. C. (2012). Melhoramento genético e cultivares de amora-preta e mirtilo. Informe Agropecuário, 33, 11-20.

Reyes-Carmona, J., Yousef, G. G., Martínez-Peniche, R. A., \& Lila, M. A. (2005). Antioxidant capacity of fruit extract of blackberry (Rubus spp.) produced in different climate regions. Journal of Food Science, 70(7), 497-503. http://dx.doi.org/10.1111/j.1365-2621.2005.tb11498.x.

Rodríguez-Hidalgo, S., Artés-Hernández, F., Gómez, P. A., Fernández, J. A., \& Artés, F. (2010). Quality of fresh-cut baby spinach grown under a floating trays system as affected by nitrogen fertilisation and innovative packaging treatments. Journal of the Science of Food and Agriculture, 90(6), 1089-1097. PMid:20355151.

Sellappan, S., Akoh, C. C., \& Krewer, G. (2002). Phenolic compounds and antioxidant capacity of Georgia-grown blueberries and blackberries. Journal of Agricultural and Food Chemistry, 50(8), 2432-2438. http:// dx.doi.org/10.1021/jf011097r. PMid:11929309.

Singleton, V. L., \& Rossi, J. A. (1965). Colorimetry of total phenolics with phosphomolybdic-phosphotungstic acid reagents. American Journal of Enology and Viticulture, 16, 144-158.

Siriwoharn, T., \& Wrolstad, R. E. (2004). Characterization of phenolics in Marion and Evergreen blackberries. Journal of Food Science, 69, 233-240

Souza, V. R., Pereira, P. A. P., da Silva, T. L., de Oliveira Lima, L. C., Pio, R., \& Queiroz, F. (2014). Determination of the bioactive compounds, antioxidant activity and chemical composition of Brazilian blackberry, red raspberry, strawberry, blueberry and sweet cherry fruits. Food Chemistry, 156, 362-368. http://dx.doi. org/10.1016/j.foodchem.2014.01.125. PMid:24629981.

Szajdek, A., \& Borowska, E. J. (2008). Bioactive compounds and health-promoting properties of berry fruits: a review. Plant Foods for Human Nutrition, 63(4), 147-156. http://dx.doi.org/10.1007/ s11130-008-0097-5. PMid:18931913.

Tarazona-Díaz, M. P., Viegas, J., Moldao-Martins, M., \& Aguayo, E. (2011). Bioactive compounds from flesh and by-product of fresh-cut watermelon cultivars. Journal of the Science of Food and Agriculture, 91(5), 805-812. http://dx.doi.org/10.1002/jsfa.4250. PMid:21384347.

Wada, L., \& Ou, B. (2002). Antioxidant activity and phenolic content of Oregon caneberries. Journal of Agricultural and Food Chemistry, 50(12), 3495-3500. http://dx.doi.org/10.1021/jf011405l. PMid:12033817.

Wang, S. Y., Bowman, L., \& Ding, M. (2008). Methyl jasmonate enhances antioxidant activity and flavonoid content in blackberries (Rubus sp.) and promotes antiproliferation of human cancer cells. Food Chemistry, 107, 1261-1269.

Zhang, L., Zhou, J., Liu, H., Khan, M. A., Huang, K., \& Gu, Z. (2012). Compositions of anthocyanins in blackberry juice and their thermal degradation in relation to antioxidant activity. European Food Research and Technology, 235(4), 637-645. http://dx.doi.org/10.1007/ s00217-012-1796-6. 